\title{
Ueber die
}

\section{Lage von Tigranokerta.}

Von

Eduard Sachau.

Aus den Abhandlungen der Königl. Akademie der Wissenschaften zu Berlin 1880.

Mit 2 Karten.

Berlin 1881.

Verlag der Königlichen Akademie der Wissenschaften. 
Vorgelegt in der Akademie der Wissenschaften am 8. November 1880. 